\title{
Pengaruh Peran dan Motivasi Penyuluh Pertanian Terhadap Inovasi Teknologi Budidaya Tanaman Padi Sawah di Kecamatan Kupang Timur, Kabupaten Kupang Provinsi Nusa Tenggara Timur
}

\section{The Effect of Agricultural Extension Agent's Role and Motivation on Wet-Rice Cultivation Technology Innovation in East Kupang Sub District of Kupang Regency of East Nusa Tenggara Province}

\author{
Wely Yitro Pello ${ }^{1}$, Emi Renoat ${ }^{2}$, Musa F. Banunaek ${ }^{1}$ \\ ${ }^{1}$ Staf Pengajar pada Program Studi Penyuluhan Pertanian Lahan Kering, Politeknik Pertanian Negeri Kupang \\ ${ }^{2}$ Staf Pengajar pada Program Studi Menejemen Sumber Daya Hutan, Politeknik Pertanian Negeri Kupang
}

\begin{abstract}
This research aimed to find out rice plant technology innovation level in East Kupang Sub District, to find out the effect of extension agent's role and job motivation on rice plant technology innovation, and to find out the simultaneous effect of extension agent's role and motivation on rice plant technology innovation. Data analysis was conducted using multiple regression analysis. The result of research found that Rice Plant Cultivation Technology Innovation (Y) in East Kupang Sub District belonged to medium category (78.33\%); it is indicated with the aspect of rice plant cultivation technology innovation dissemination by extension agent of $74.50 \%$ only and the aspect of farmers' participation in wet-rice cultivation technology of $66.17 \%$. The agricultural extension agent's role factor belonged to high category (50.00\%), while agricultural extension agent's motivation factor belonged to medium category (60.00\%). Agricultural Extension Agent factor affected significantly the rice cultivation technology innovation $(Y)$, as indicated with three aspects: extension agent's role as educator and facilitator, role as analyzer and planner, and role as evaluation expert of activity and education result. Agricultural extension agent's motivation factor significantly affected the rice cultivation technology innovation $(Y)$, as indicated with three aspects: extension agent's motivation on basic need, status/social need, and work performance need. Extension agent's role and motivation simultaneously affected rice plant technology innovation with $F_{\text {statistic }}$ value of 13.11 .
\end{abstract}

Keywords: Rice Plant Cultivation Technology Innovation, Agricultural Extension Agent's Role, Agricultural Extension Agent's Motivation

\begin{abstract}
Abstrak
Penelitian ini bertujuan untuk mengetahui tingkat inovasi teknologi tanaman padi di Kecamatan Kupang Timur; mengetahui pengaruh peran dan motivasi kerja penyuluh terhadap inovasi teknologi tanaman padi dan mengetahui pengaruh secara simultan pengaruh peran dan motivasi penyuluh terhadap inovasi teknologi tanaman padi. Analisis data menggunakan analisis regresi berganda. Hasil penelitian menemukan bahwa tinggkat Inovasi Teknologi Budidaya Tanaman Padi (Y) di Kecamatan Kupang Timur berada dalam kategori Sedang (78.33\%), hal ini ditunjukan oleh aspek penyebaran inofasi teknologi budidaya tanaman padi oleh penyuluh hanya sebesar 74.50 \% dan aspek partisipasi petani terhadap inovasi teknologi budidaya tanaman padi sawah hanya sebesar $66.17 \%$. Faktor peran penyuluh pertanian berada pada tingkat kategori tinggi (50.00 \%) sedangkan faktor motivasi penyuluh pertanian berada pada tingkat kategori sedang (60,00\%). Faktor Peran Penyuluh Pertanian secara signifikan berpengaruh pada inovasi teknologi budidaya tanaman padi (Y) hal ini ditunjukan oleh tiga aspek yaitu aspek peran penyuluh sebagai pendidik dan pendamping, aspek peran sebagai analisator dan perencana dan aspek sebagai ahli evaluasi kegiatan dan hasil penyuluhan. Faktor motivasi penyuluh pertanian secara signifikan berpengaruh pada inovasi teknologi budidaya tanaman padi (Y), hal ini ditunjukan oleh tiga aspek yaitu motivasi penyuluh terhadap kebutuhan dasar, kebutuhan status/sosial dan kebutuhan prestasi kerja. Secara simultan peran dan motivasi penyuluh berpengaruh terhadap inovasi teknologi tanaman padi dengan nilai $\mathrm{F}_{\text {hitung }}$ sebesar 13,11.
\end{abstract}

Kata kunci : Inovasi Teknologi Budidaya Tanaman Padi , Peran Penyuluh, Motivasi Penyuluh Pertanian

\footnotetext{
${ }^{1}$ Korespondensi penulis

E-mail: engki_banunaek@yahoo.com
} 


\section{Pendahuluan}

Kementerian Pertanian menetapkan target pembangunan pertanian, khusus untuk tahun 2018 ditetapkan sasaran produksi tujuh komoditas unggulan yang harus dicapai, yaitu: padi 80,08 juta ton, jagung 23,48 juta ton, kedelai 2,34 juta ton, tebu 3,30 juta ton, aneka cabai 2,23 juta ton, bawang merah 1,37 juta ton, serta daging sapi dan kerbau 0,69 juta ton (Renstra Kementan 2015-2019). Untuk mencapai target tersebut diharapkan semua lembaga baik yang ada dipusat maupun daerah turut berperan aktif dalam mendukung tercapainya tujuh komoditas unggul ini.

Salah satu lembaga yang turut berperan adalah lembaga perguruan tinggi dimana diharapkan dapat memberikan informasi dan hasil riset yang membantu petani sehingga bisa meningkatkan hasil usaha komoditas yang dibudidayakannya. Salah satu perguruan tinggi yang turut berperan aktif dalam pengabdian terhadap masyarakat adalah Politeknik Pertanian Negeri Kupang dimana dalam rencana Induk Penelitian Politani Kupang khususnya di bidang penyuluhan pertanian lahan kering, salah satu isu strategis di bidang penyuluh pertanian yaitu masih banyak masyarakat yang memiliki budaya prilaku pengelolaan usaha tani yang pada umumnya masih tradisional serta akses terhadap informasi input produksi yang masih rendah.

Salah satu usaha yang perlu dilakukan demi mengurangi budaya prilaku pengelolaan usaha tani yang masih tradisional adalah dengan memanfaatkan motivasi dan peran penyuluh melalu pendampingan, pendidikan yang di kembangkan oleh penyuluh sehingga petani dididik dan dilatih dengan pendekatan informasi, hasil riset yang baik dan pengunaan teknologi budidaya tanaman yang baik dan ada penambahan pengetahuan dari masyarakat/petani tersebut sehingga petani bisa merubah prilakunya dari pengelolaan usaha tani yang tradisional ke penggunaan teknologi dan mampu mengakses input produksi yang tinggi sehingga menghasilkan produksi hasil yang tinggi. Salah satu daerah yang memiliki jumlah poktan cukup banyak dan pada umumnya masih menerapkan budaya usaha tani yang tradisional adalah Kecamatan Kupang Timur dengan jumlah kelompok taninya sebanyak 80 kelompok dengan luas lahan sawahnya di tahun 2015 mencapai 5856 ha (BPS Kab. Kupang 2017).

Dari isu strategi penyuluhan diatas maka perlu dilakukan suatu kajian yang bertujuan untuk mengetahui jangka panjang yaitu perubahan prilaku petani dari budaya usaha tani padi sawah yang tradisional kepenggunaan inovasi teknologi tanaman padi selama 5 tahun terakhir. Untuk itu maka beberapa target jangka pendek yang perlu di kaji mendalam yaitu (1). Mengetahui Tingkat Inovasi Teknologi Tanaman Padi di Kecamatan Kupang Timur.(2). Menganalisis pengaruh Peran Penyuluh Terhadap Inovasi Teknologi Tanaman Padi di Kecamatan Kupang Timur. (3). Menganalisis Pengaruh Motivasi Kerja Penyuluh terhadap Inovasi Teknologi Tanaman Padi di Kecamatan Kupang Timur dan (4). Menganalisis pengaruh secara simultan pengaruh Peran Penyuluh dan Motivasi Kerja terhadap Inovasi Teknologi Tanaman Padi di Kecamatan Kupang Timur.

\section{Metode Penelitian}

Daerah penelitian ditentukan secara Purposive yaitu pada Badan Pelaksana Penyuluhan Pertanian, Perikanan Dan Kehutanan dan Kelompok Tani Padi sawah di Kecamatan Kupang Timur. Menurut Sugiyono (2010:85) sampling purposive adalah "teknik penentuan sampel dengan pertimbangan tertentu." Artinya setiap subjek yang diambil dari populasi dipilih dengan sengaja berdasarkan tujuan dan pertimbangan tertentu. 
Jenis penelitian yang digunakan adalah ex post facto, yaitu bentuk penelitian yang menilai peristiwa yang telah terjadi atau penilaian kondisi faktual di lapangan. Peubah-peubah penelitian meliputi peubah bebas (X) dan peubah terikat (Y). Peubah bebas (X), terdiri dari: Peran Penyuluh dan Motivasi Penyuluh. Peubah terikat (Y) Yaitu Inovasi Teknologi Budidaya Padi di Kecamatan Kupang Timur.

Dalam penelitian ini teknik pengambilan sampel yaitu $10 \%$ dari jumlah total populasi yang ada dimana jumlah petani dan jumlah penyuluh di Kecamatan Kupang Timur kurang lebih sekitar 600 orang sehingga sampel yang diambil sebanyak 10 $\%$ atau sebanyak 60 orang responden yang terdiri dari Penyuluh sebanyak 11 orang atau seluruh penyuluh yang ada dan Petani sebanyak 49 orang. Sugiyono (2013:80). Sampel adalah bagian dari jumlah dan karakteristik yang dimiliki oleh populasi tersebut, selanjutnya Arikunto (2006:134) mengatakan bahwa apabila populasi kurang dari 100 orang, maka sampel di ambil secara keseluruhan, sedangkan populasi di atas 100, maka sampel di ambil 10\% - 15\% atau $20 \%$ - $25 \%$ dari populasi.

Pengumpulan data dilakukan menggunakan FGD dan kuesioner dengan mengajukan pertanyaan terbuka dan tertutup kepada seluruh penyuluh pertanian dan Kelompok Petani padi sawah dengan alternatif jawaban menggunakan skala Likert sedangkan analisis data untuk mengetahui hasil jawaban menggunakan analisis regresi linier berganda.

\section{Hasil dan Pembahasan}

\section{Analisis Tingkat Inovasi Teknologi Budidaya Tanaman Padi Sawah di Kecamatan Kupang Timur}

Adapun indikator penilaian inovasi teknologi budidaya tanaman padi yang meliputi: penyebaran informasi inovasi teknologi budidaya tanaman padi oleh penyuluh dan partisipiasi petani terhadap inovasi teknologi budidaya tanaman padi. Responden memberikan penilaian sebesar 74,50 \% terhadap sub variable penyebaran informasi inovasi teknologi budidaya

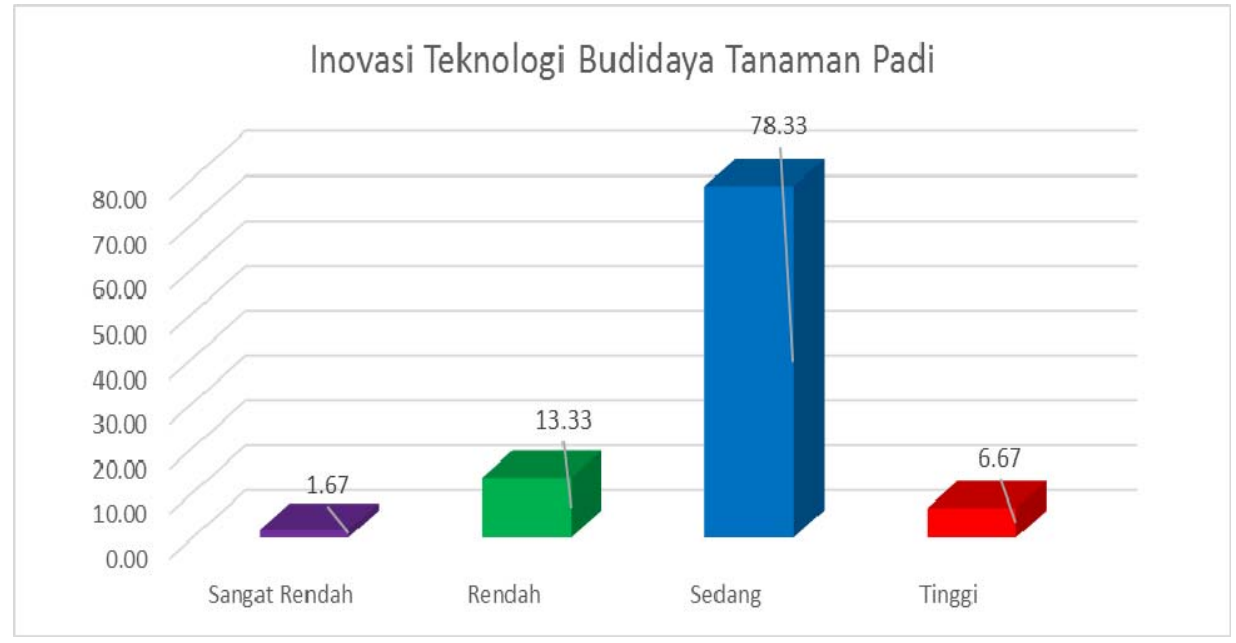

Gambar 1. Grafik Inovasi Teknologi Budidaya Tanaman Padi

Deskripsi data penelitian variabel Inovasi teknologi budidaya tanaman padi (Y) tersaji pada gambar 1. Pada Gambar 1 dapat dilihat bahwa responden lebih banyak memberikan penilaian terhadap variabel inovasi teknologi budidaya tanaman padi pada kriteria sedang yaitu sebanyak 47 (empat puluh tujuh) orang dari 60 (enam puluh) orang atau sebesar 78,33 \%. Adapun perincianya sesuai Tabel 1 dibawah yaitu 
Tabel 1. Distribusi Penilaian Responden Berdasarkan Masing-Masing Sub Variabel

\begin{tabular}{|c|c|c|c|c|}
\hline No & Inovasi Teknologi Budidaya Tanaman Padi & \begin{tabular}{|c|}
$\begin{array}{c}\text { Interval } \\
\text { Skor }\end{array}$ \\
\end{tabular} & \begin{tabular}{|c|} 
Skor \\
Capaian \\
\end{tabular} & $\begin{array}{c}\text { Presentase } \\
\text { Capaian }\end{array}$ \\
\hline $\mathbf{A}$ & $\begin{array}{l}\text { Penyebaran Informasi Inovasi Teknologi Budidaya Tanaman } \\
\text { Padi Oleh Penyuluh }\end{array}$ & 1-20 & 14.90 & 74.50 \\
\hline 1 & $\begin{array}{l}\text { Penyuluh membantu petani menggunakan teknologi budidaya padi } \\
\text { sawah organik }\end{array}$ & $1-4$ & 3.43 & 85.83 \\
\hline 2 & $\begin{array}{l}\begin{array}{l}\text { Penyuluh membantu petani menerapkan teknologi pertanian } \\
\text { berkelanjutan }\end{array} \\
\end{array}$ & $1-4$ & 3.40 & 85.00 \\
\hline 3 & $\begin{array}{l}\text { Penyuluh membantu petani menerapkan budidaya tanaman padi } \\
\text { dengan metode SRI. }\end{array}$ & $1-4$ & 2.52 & 62.92 \\
\hline 4 & $\begin{array}{l}\text { Penyuluh membantu petani menerapkan teknologi budidaya } \\
\text { tanaman padi dengan sistem tanam jajar legowo }\end{array}$ & $1-4$ & 3.67 & 91.67 \\
\hline 5 & $\begin{array}{l}\text { Penyuluh membantu petani menerapkan teknologi budidaya } \\
\text { tanaman padi dengan sistem haston. }\end{array}$ & $1-4$ & 1.88 & 47.08 \\
\hline B & $\begin{array}{l}\text { Partisipiasi Petani terhadap Inovasi Teknologi Budidaya } \\
\text { Tanaman Padi }\end{array}$ & 1-20 & 13.23 & 66.17 \\
\hline 6 & $\begin{array}{l}\text { Partisipiasi Petani menggunakan teknologi budidaya padi sawah } \\
\text { organik }\end{array}$ & $1-4$ & 3.13 & 78.33 \\
\hline 7 & Partisipiasi Petani menerapkan teknologi pertanian berkelanjutan & $1-4$ & 2.20 & 55.00 \\
\hline 8 & $\begin{array}{l}\text { Partisipiasi petani menerapkan budidaya tanaman padi dengan } \\
\text { metode SRI. }\end{array}$ & $1-4$ & 2.90 & 72.50 \\
\hline 9 & $\begin{array}{l}\text { Partisipiasi petani menerapkan teknologi budidaya tanaman padi } \\
\text { dengan sistem tanam jajar legowo }\end{array}$ & $1-4$ & 3.33 & 83.33 \\
\hline 10 & $\begin{array}{l}\text { Partisipiasi petani menerapkan teknologi budidaya tanaman padi } \\
\text { dengan sistem haston. }\end{array}$ & $1-4$ & 1.67 & 41.67 \\
\hline
\end{tabular}

Sumber: Analisis data 2018

tanaman padi oleh penyuluh sedangkan sub variabel partisipasi petani terhadap inovasi teknologi budidaya tanaman padi hanya sebesar $66,17 \%$.

Berdasarkan hasil analisis pada Gambar 1 diatas menunjukan bahwa sebagian besar responden cenderung menilai sedang terhadap variabel inovasi teknologi budidaya tanaman padi. Penilaian sedang yang diberikan responden ini di latar belakangi karena banyak petani dan penyuluh hanya memberikan penilaian sedang pada sub variabel yang ada misalnya pada sub varibel penyebaran informasi teknologi budidaya tanaman padi sawah oleh penyuluh sesuai Tabel 1 yang menunjukan bahwa kebanyak penyuluh hanya menyebarkan informasi inovasi teknologi budidaya tanaman padi dengan sistem tanam jajar legowo saja dibandingkan dengan teknologi budidaya tanaman padi yang lain. Hasil ini juga sejalan dengan sub variabel partisipasi petani terhadap inovasi teknologi budidaya tanaman padi, dimana dari Tabel 1 yang menunjukan bahwa petani lebih cenderung berpartisipasi dalam mengikuti informasi dan mengadopsi informasi inovasi teknologi budidaya tanaman padi dengan sistem tanam jajar legowo saja dibandingkan dengan teknologi budidaya tanaman padi sawah yang lain.

Dari hasil FGD sesuai Gambar 2 dibawah, penyuluh dan petani memberikan informasi bahwa sebenarnya penyuluh sudah memberikan informasi terbaru mengenai sehingga air yang mengalir melewati tehnologi budidaya tanaman padi sawah baik teknologi budidaya tanaman padi sawah organik, teknologi pertanian 


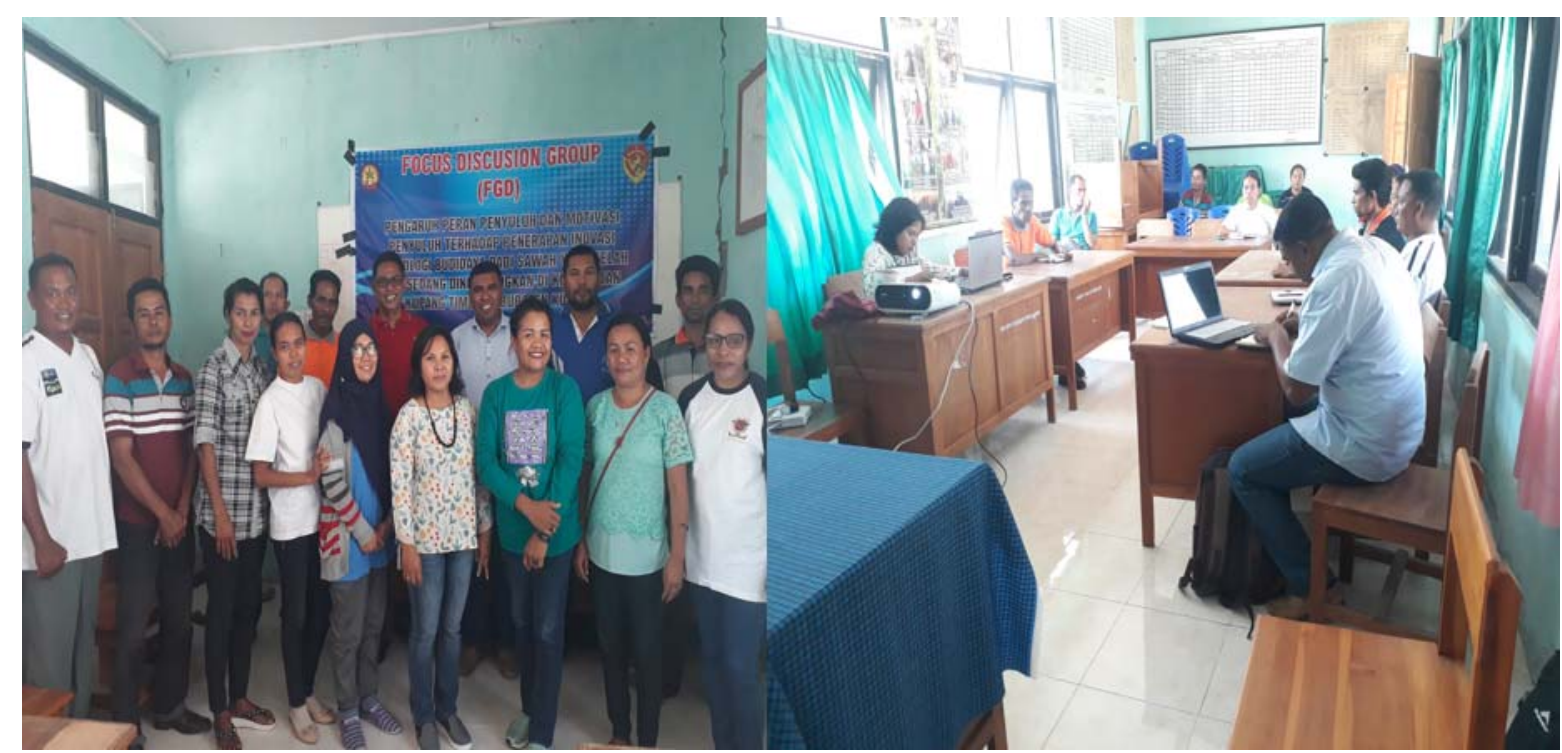

Gambar 2. Hasil Focus Group Discussion (FGD) dengan Penyuluh dan Petani Padi Sawah Kecamatan Kupang Timur

berkelanjutan maupun budidaya tanaman padi dengan sistem haston, namun banyak petani lebih mengadopsi budidaya tanaman padi dengan sistem tanam jajar legowo, sehingga menyebabkan tingkat inovasi teknologi budidaya tanaman padi sawah di Kecamatan Kupang Timur dikategorikan sedang.

Petani cenderung berpartisipasi dan mengadopsi teknologi budidaya tanaman padi dengan sistem tanam jajar legowo dikarenakan Teknik dan penerapanya lebih mudah dibandingkan dengan teknologi budidaya tanaman padi yang lain, misalnya teknologi budidaya tanaman padi sawah organik, dimana petani mengatakan bahwa petani pernah mempraktekan budidaya padi Organik namun membutuhkan biaya dan perawatan yang lebih tinggi dimana mayoritas petani yang ada di Kecamatan Kupang Timur masih menggunakan pestisida dan juga pupuk anorganik saluran irigasi tercemar dengan pupuk anorganik dan pestisida yang ada sehingga petani kesulitan dalam menerapkan budidaya padi organik. Penyuluh dan petani menambahkan bahwa tingkat inovasi teknologi budidaya tanaman padi dikategorikan sedang disebabkan juga karena faktor iklim dimana Provinsi NTT dan Khususnya Kecamatan Kupang Timur curah hujannya sangat rendah hanya sekitar 4 bulan basa saja sehingga petani hanya memanfaatkan 4 bulan basa tersebut untuk menanam tanaman padi atau dalam 1 tahun petani hanya menanam tanaman padi sawah hanya 1 kali saja, yaitu pada 4 bulan basa tersebut, sehingga menyebabkan petani kesulitan dalam melakukan percobaan penggunaan teknologi budidaya tanaman padi yang ada.

\section{Pengaruh Secara Simultan Peran Penyuluh Pertanian dan Motivasi Penyuluh Pertanian terhadap Inovasi Teknologi Budidaya Tanaman Padi Sawah di Kecamatan Kupang Timur}

Hasil analisis inovasi teknologi budidaya tanaman padi sawah secara simultan yang dipengaruhi oleh peran penyuluh pertanian dan motivasi penyuluh pertanian disajikan pada tabel 2.

Berdasarkan Tabel 2. Maka dapat disimpulkan bahwa Fhitung $>F_{\text {tabel }}$ $(13,11>2,02)$, maka $\mathrm{H}_{0}$ ditolak, artinya bahwa peran penyuluh dan motivasi 
Tabel 2. Hasil Uji Pengaruh secara Simultan Faktor Peran Penyuluh dan Motivasi Penyuluh Pertanian terhadap Inovasi Teknologi Budidaya Tanaman Padi Sawah.

\begin{tabular}{|l|c|c|c|}
\hline \multicolumn{1}{|c|}{ Model } & Jumlah Kuadrat & f hitung & Signifikan \\
\hline Regresi & 315,177 & 13,119 & $0.000^{\mathrm{b}}$ \\
\hline Residual & 685,962 & & \\
\hline Total & 1001,7 & & \\
\hline Nilai signifikan 0,05 & \multicolumn{3}{|l|}{} \\
\hline
\end{tabular}

penyuluh pertanian secara Bersama-sama berpengaruh terhadap inovasi teknologi budidaya tanaman padi sawah di Kecamatan Kupang Timur.

\section{Pengaruh Secara Parsial Peran Penyuluh Pertanian dan Motivasi Penyuluh Pertanian Terhadap Inovasi Teknologi Budidaya Tanaman Padi Sawah di Kecamatan Kupang Timur}

Pengaruh Secara Parsial Peran Penyuluh Pertanian dan Motivasi Penyuluh Pertanian Terhadap Inovasi Teknologi Budidaya
Tanaman Padi Sawah di Kecamatan Kupang Timur disajikan pada Tabel 3.

Dari hasil analisis pada Tabel 3 diatas menunjukan bahwa terdapat pengaruh signifikan dari faktor peran penyuluh pertanian dan motivasi penyuluh pertanian terhadap inovasi teknologi budidayatanaman padi sawah di Kecamatan Kupang Timur, hal ini menunjukan bahwa setiap kenaikan peran dan motivasi penyuluh maka akan dapat meningkatkan tingkat inovasi teknologi budidaya tanaman padi sawah.

Tabel 3. Hasil Uji Pengaruh secara Parsial Faktor Peran Penyuluh dan Motivasi Penyuluh Pertanian terhadap Inovasi Teknologi Budidaya Tanaman Padi Sawah.

\begin{tabular}{|l|c|c|c|c|}
\hline \multicolumn{1}{|c|}{ Uraian } & $\boldsymbol{\beta}$ & t hitung & Sign & Ket \\
\hline (konstan) & 7,178 & 1,740 & 0,087 & \\
\hline Peran Penyuluh Pertanian & 0,329 & 3,403 & 0,001 & Sangat Signifikan \\
\hline Motivasi Penyuluh Pertanian & 0,312 & 2,921 & 0,005 & Sangat Signifikan \\
\hline $\mathrm{T}_{\text {tabel }: 2,02}$ & & & & \\
\hline
\end{tabular}

Sumber: Analisis data 2018

Pengaruh Peran Penyuluh Pertanian Terhadap Inovasi Teknologi Budidaya Tanaman Padi Sawah

Tabel 3 menunjukan bahwa peran penyuluh pertanian berpengaruh terhadap penerapan inovasi teknologi budidaya tanaman padi sawah. Artinya bahwa setiap kenaikan peran penyuluh pertanian maka akan berdanpak positif terhadap peningkatan penerapan inovasi teknologi budidaya tanaman padi sawah. Hal ini disebabkan karena rata-rata 88,47 persen (Tabel 4) responden mengatakan bawah penyuluh selalu melakukan pendidikan dan pendampingan terhadap petani binaan.
Pendidikan dan pendampingan yang dilakukan terus menerus oleh penyuluh akan menambah pengetahuan dari petani terhadap inovasi teknologi yang ada sehingga petani binaan akan terdorong untuk mengadopsi teknologi inovasi padi sawah yang dikembangkan dan juga inovasi teknologi budidaya tanaman padi yang baru. Hasil ini sejalan dengan pendapat Rogers (2003) dalam Asnamawati (2015) mengatakan bahwa petani memutuskan untuk menerima atau menolak inovasi melalui tahapan pengetahuan, persuasi, keputusan, implementasi dan konfirmasi. Artinya bahwa peran penyuluh pertanian yang ada di Kecamatan Kupang Timur cukup tinggi sehingga mampu menambah 
pengetahuan dari petani padi sawah akan informasi inovasi teknologi budidaya tanaman padi dan merubah pola piker petani untuk mau menerima inovasi teknologi budidaya tanaman padi yang ada. Hasil peranan penyuluh Kecamatan Kupang Timur sejalan dengan pendapat Mardikanto (2009) dalam Ridwan (2013) yang menyatakan bahwa ada 3 indikator peran penyuluh sebagai diseminisai atau penyebarluasan informasi atau inovasi antaralain yaitu pertama, memberikan pendampingan dan bimbingan teknis kepada petani binaan; kedua, memperkenalkan program yang ada dan ketiga, menyampaikan informasi inovasi terbaru kepada masyarakat atau petani. Selain faktor diatas, didukung pula oleh perencanaan yang baik (Tabel 4), perencanaan yang berpusat pada permasalahan atau kebutuhan dari petani akan mengarahkan penyuluh sehingga menyusun kegiatan atau pemberian informasi teknologi yang sesuai dengan kebutuhan petani sehingga dengan kegiatan yang sesuai atau informasi inovasi teknologi yang tepat maka akan menjawab kebutuhan dari petani.

Tabel 4. Distribusi Penilaian Responden Berdasarkan Masing-Masing Sub Variabel Peran Penyuluh Pertanian

\begin{tabular}{|c|c|c|c|c|}
\hline No & Peran Penyuluh Pertanian & $\begin{array}{l}\text { Interval } \\
\text { Skor }\end{array}$ & $\begin{array}{c}\text { Skor } \\
\text { Capaian }\end{array}$ & $\begin{array}{c}\text { Presentase } \\
\text { Capaian }\end{array}$ \\
\hline $\mathbf{A}$ & Peran Sebagai Pendidik dan Pendamping & $1-12$ & 10.62 & 88.47 \\
\hline 1 & $\begin{array}{l}\text { Mengajarkan kepada petani tentang budidaya tanaman } \\
\text { yang baik }\end{array}$ & $1-4$ & 3.70 & 92.50 \\
\hline 2 & Membimbing dan mendampingi & $1-4$ & 3.45 & 86.25 \\
\hline 3 & $\begin{array}{l}\text { Petani binaan menginginkan penyuluh mengajarkan dan } \\
\text { mendampingi }\end{array}$ & $1-4$ & 3.47 & 86.67 \\
\hline B & Peran Sebagai Analisator dan Perencana & $1-16$ & 13.67 & 85.42 \\
\hline 4 & $\begin{array}{l}\text { Memfasilitasi petani padi sawah dalam memperoleh } \\
\text { informasi }\end{array}$ & $1-4$ & 3.65 & 91.25 \\
\hline 5 & Menganalisis permasalahan utama Petani & $1-4$ & 3.40 & 85.00 \\
\hline 6 & $\begin{array}{l}\text { Bekerja sama dalam merencanakan kegiatan budidaya } \\
\text { padi sawah }\end{array}$ & $1-4$ & 3.43 & 85.83 \\
\hline 7 & $\begin{array}{|lll|}\text { Petani menginginkan penyuluh bekerja sama } \\
\text { merencanakan kegiatan budidaya padi sawah }\end{array}$ & $1-4$ & 3.18 & 79.58 \\
\hline $\mathbf{C}$ & $\begin{array}{l}\text { Peran Sebagai Ahli evaluasi kegiatan dan hasil } \\
\text { Penyuluhan }\end{array}$ & $1-12$ & 8.82 & 73.47 \\
\hline 8 & $\begin{array}{l}\text { Penyuluh Menerapkan evaluasi disetiap menyelesaikan } \\
\text { kegiatan penyuluhan padi sawah }\end{array}$ & $1-4$ & 3.17 & 79.17 \\
\hline 9 & \begin{tabular}{|l} 
Evaluasi kegiatan penyuluhan membantu penyuluh \\
menilai keberhasilan kegiatan
\end{tabular} & $1-4$ & 2.87 & 71.67 \\
\hline 10 & $\begin{array}{l}\text { Petani membantu dalam melaksanakan evaluasi kegiatan } \\
\text { penyuluhan }\end{array}$ & $1-4$ & 2.78 & 69.58 \\
\hline
\end{tabular}

Terjawabnya kebutuhan atau terpenuhinya informasi inovasi teknologi dari petani maka akan menambah pengetahuan dari petani untuk mau mencoba menerapkan inovasi teknologi tersebut dan pada akhirnya ada perubahan prilaku petani kearah penerapan inovasi teknologi. Hasil penelitian ini sejalan dengan penelitian Wirasyahputra, (2012) yang menemukan bahwa Peran penyuluh, motivasi dan sikap mempengaruhi proses adopsi inovasi padi sawah. Hasil ini didukung pula dengan penelitian Irwandi., Dkk (2016) yang menemukan bahwa penyuluh sangat 
Tabel 5. Distribusi Penilaian Responden Berdasarkan Masing-Masing Sub Variabel Motivasi Penyuluh Pertanian

\begin{tabular}{|c|c|c|c|c|}
\hline No. 1 & Motivasi Penyuluh Pertanian & \begin{tabular}{|c|} 
Interval \\
Skor
\end{tabular} & Skor Capaian & $\begin{array}{l}\text { Presentase } \\
\text { Capaian }\end{array}$ \\
\hline A 1 & Dorongan untuk memenuhi kebutuhan dasar penyuluh. & 1-12 & 8.83 & 73.61 \\
\hline 1 & Ingin bekerja untuk memenuhi kebutuhan dasar & $1-4$ & 2.90 & 72.50 \\
\hline $2 \mathrm{I}$ & $\begin{array}{l}\text { Ingin bekerja untuk meningkatkan pendapatan agar dapat } \\
\text { memenuhi kebutuhan keluarga }\end{array}$ & $1-4$ & 3.12 & 77.92 \\
\hline 3 & $\begin{array}{l}\text { Ingin bekerja di BP3K karena sebagian besar kebutuhan dasar } \\
\text { dapat dipenuhi. }\end{array}$ & $1-4$ & 2.82 & 70.42 \\
\hline B & Dorongan untuk memenuhi kebutuhan status. & 1-12 & 9.40 & 78.33 \\
\hline 4 & $\begin{array}{l}\text { Ingin bekerja sebagai penyuluh karena dapat berinteraksi } \\
\text { dengan banyak orang }\end{array}$ & $1-4$ & 3.42 & 85.42 \\
\hline 5 & $\begin{array}{l}\text { Ingin bekerja sebagai penyuluh karena ingin diakui/diterima } \\
\text { oleh keluarga, masyarakat dan instansi }\end{array}$ & $1-4$ & 3.07 & 76.67 \\
\hline 6 & $\begin{array}{l}\text { Ingin bekerja agar dapat dihargai oleh keluarga, masyarakat } \\
\text { dan instansi }\end{array}$ & $1-4$ & 2.92 & 72.92 \\
\hline C & \begin{tabular}{|l} 
Dorongan untuk memenuhi kebutuhan berprestasi \\
penyuluh
\end{tabular} & $1-16$ & 13.87 & 86.67 \\
\hline 7 & $\begin{array}{l}\text { Ingin bekerja untuk menunjukan hasil kerja kepada instansi, } \\
\text { keluarga maupun masyarakat bahwa saya mampu berprestasi }\end{array}$ & $1-4$ & 3.43 & 85.83 \\
\hline 8 & $\begin{array}{l}\text { Ingin bekerja untuk meningkatkan prestasi kerja sesuai yang } \\
\text { diharapkan. }\end{array}$ & $1-4$ & 3.52 & 87.92 \\
\hline \begin{tabular}{l|l} 
& I \\
\end{tabular} & $\begin{array}{l}\text { Ingin bekerja untuk menjadi seorang yang berprestasi pada } \\
\text { instansi penyuluhan }\end{array}$ & $1-4$ & 3.45 & 86.25 \\
\hline 10 & $\begin{array}{l}\text { Ingin bekerja untuk meningkatkaan kinerja agar sesuai target } \\
\text { yang diharapkan oleh instansi penyuluhan pertanian }\end{array}$ & $1-4$ & 3.47 & 86.67 \\
\hline otal & & & & \\
\hline
\end{tabular}

Sumber: Analisis data 2018

berperan dalam proses adopsi inovasi padi sistem jajar legowo di lahan pasang surut. Selain itu juga sejalan dengan hasil penelitian Jalil., Dkk (2015) yang menemukan bahwa peran penyuluh yang baik akan mampu membimbing petani sehingga petani akan aktif dalam mengikuti program yang ada.

\section{Pengaruh Motivasi Penyuluh Terhadap Inovasi Teknologi Budidaya Tanaman Padi Sawah}

Motivasi penyuluh pertanian merupakan adanya dorongan internal dan eksternal dari seorang penyuluh dalam melaksanakan tugas pokoknya. Sesuai Tabel 3 diatas menunjukan bahwa motivasi memberikan pengaruh positif dan sangat signifikan terhadap inovasi teknologi budidaya tanaman padi sawah. Dapat diartikan bahwa semakin meningkatnya motivasi kerja dari penyuluh akan diikuti pula dengan kenaikan inovasi teknologi budidaya tanaman padi. Tingginya motivasi penyuluh yang ada di Kecamatan Kupang Timur dilatar belakangi oleh adanya dorongan untuk memenuhi kebutuhan berprestasi yaitu sebanyak 86,67 persen responden penyuluh (Tabel 5) yang memilih untuk memenuhi kebutuhan prestasi kerjanya. Kebutuhan untuk berprestasi inilah yang mendorong penyuluh untuk melakukan pendampingan dan penyebarluasan informasi kepada petani dengan baik sehingga petani mendapatkan pengetahuan yang cukup tentang informasi atau inovasi teknologi budidaya tanaman padi yang ada sehingga petani mudah untuk mengadopsi inovasi teknologi budidaya tanaman padi tersebut.

Hal ini sejalan dengan pendapat dari Gibson dkk (2012) menyatakan bahwa motivasi 
sebagai suatu dorongan yang timbul pada atau di dalam seorang individu yang menggerakkan dan mengarahkan perilaku. Oleh karena itu, motivasi dapat berarti suatu kondisi yang mendorong atau menjadi sebab seseorang melakukan suatu perbuatan/kegiatan yang berlangsung secara wajar. Menurut Nawawi (2001) bahwa kata motivasi (motivation) kata dasarnya adalah motif (motive) yang berarti dorongan, sebab atau alasan seseorang melakukan sesuatu. Gibson juga mengatakan bahwa kebutuhan dipandang sebagai penggerak atau pembangkit perilaku. Artinya, jika kebutuhan akibat kekurangan itu muncul, maka individu lebih peka terhadap usaha motivasi untuk meningkatkan perilaku bekerja dengan baik untuk memenuhi kebutuhan tersebut.

Hasil penelitian ini juga mendukung teori motivasi ERG. Dalam Teori ERG ini kebutuhan manusia oleh Aldefer dibagi dalam tiga tingkatan. Gibson, dkk. (2012) menjelaskan ketiga tingkat sebagai berikut: Eksistensi: kebutuhan-kebutuhan manusia akan makanan, udara, gaji, air, kondisi kerja. Kebutuhan Relasi atau Hubungan: Keterkaitan kebutuhan-kebutuhan akan adanya hubungan sosial dan interpersonal yang baik, dan pertumbuhan: kebutuhankebutuhan individu untuk memberikan kontribusi pada orang lain atau organisasi dengan memberdayakan kreatifitas, potensi dan kemampuan yang dimiliki.

Hasil penelitian ini mendukung penelitian dari Jide Ibietan (2010) dalam Banunaek (2017) tentang menghubungkan teori Motivasi dalam praktek manajemen dan dari hasil penelitiannya merekomendasikan bahwa manajer harus peka terhadap kebutuhan karyawan sehingga dengan terpenuhinya kebutuhan maka karyawan bisa mencapai kinerjanya yang baik yang berpengaruh terhadap pencapaian tujuan organisasi. Selain itu juga hasil penelitian ini sepadan dengan hasil penelitian yang dilakukan oleh Kusminarti (2013) dalam Banunaek (2017) yang menemukan bahwa motivasi kerja berpengaruh signifikan terhadap kinerja perawat, artinya semakin tinggi motivasi kerja seseorang, maka secara otomatis mempengaruhi tingkat kinerjanya. Hasil penelitian ini juga mendukung penelitian Banunaek (2017) yang menemukan bahwa motivasi penyuluh berpengaruh positif pada kinerjanya dimana semakin tinggi motivasi kerja penyuluh akan berdanpak positif pada hasil kerjanya.

\section{Kesimpulan}

Berdasarkan hasil Penelitian dan Pembahasan, maka dapat diambil suatu kesimpulan, yaitu: (1) Secara umum tinggkat Inovasi Teknologi Budidaya Tanaman Padi (Y) di Kecamatan Kupang Timur berada dalam kategori Sedang (78.33\%). Hal ini ditunjukan oleh aspek penyebaran inofasi teknologi budidaya tanaman padi oleh penyuluh hanya sebesar $74.50 \%$ dan aspek partisipasi petani terhadap inovasi teknologi budidaya tanaman padi sawah hanya sebesar $66.17 \%$ saja. (2) Faktor peran penyuluh pertanian berada pada tingkat kategori tinggi (50.00 \%) sedangkan faktor motivasi penyuluh pertanian berada pada tingkat kategori sedang (60,00\%). (3) Faktor Peran Penyuluh Pertanian secara signifikan berpengaruh pada inovasi teknologi budidaya tanaman padi (Y) di Kecamatan Kupang Timur hal ini ditunjukan oleh tiga aspek yaitu aspek peran penyuluh sebagai pendidik dan pendamping, aspek peran sebagai analisator dan perencana dan aspek sebagai ahli evaluasi kegiatan dan hasil penyuluhan. (4) Faktor motivasi penyuluh pertanian secara signifikan berpengaruh pada inovasi teknologi budidaya tanaman padi (Y) di Kecamatan Kupang Timur. Hal ini ditunjukan oleh tiga aspek yaitu motivasi penyuluh terhadap kebutuhan dasar, motivasi penyuluh terhadap kebutuhan status/sosial dan motivasi penyuluh terhadap kebutuhan prestasi. (5) Secara simultan peran penyuluh pertanian dan motivasi penyuluh pertanian berpengaruh terhadap kinerja penyuluh 
yang ditunjukan dengan nilai Fhitung sebesar 13,11 .

\section{Saran}

Adapun saran dalam penelitian ini : (1) Bagi Para Peneliti; Dari hasil penelitian ini membuktikan bahwa ada pengaruh dari faktor peran penyuluh pertanian dan motivasi penyuluh pertanian terhadap inovasi teknologi budidaya tanaman padi sawah, sehingga perlu ada penerapan penelitian selanjutnya pada daerah-daerah lain. (2) Bagi Badan Ketahanan Pangan dan Pelaksanaan Penyuluhan Pertanian, Perikanan dan Kehutanan (BP4K) Kabupaten Kupang dan Pemerintah Daerah perlu melakukan upaya optimalisasi faktorfaktor yang berpengaruh pada inovasi teknologi budidaya tanaman padi sawah sehingga akan berakibat pada adanya peningkatan adopsi inovasi teknologi budidaya tanaman padi sawah di Kabupaten Kupang. Perlu diketahui bahwa perlu adanya: (3) Perlu adanya peningkatan faktor peran penyuluh pertanian (Peran penyuluh dalam mendidik dan mendampingi, peran penyuluh sebagai analisator dan perencana, dan peran penyuluh sebagai ahli evaluasi dan hasil kegiatan penyuluhan). (4) Perlu adanya peningkatan faktor motivasi penyuluh pertanian (Motivasi akan kebutuhan dasar, motivasi akan kebutuhan status/social dan motivasi akan kebutuhan prestasi). (5) Perlu adanya peningkatan fasilitas, juga pemberian imbalan dan penghargaan yang sepantasnya sehingga mampu memicu adanya dorongan penyuluh untuk termotivasi bekerja lebih giat dalam mendampingi petani binaan baik yang ada di Kecamatan Kupang Timur maupun Penyuluh yang di Kabupaten Kupang.

\section{Daftar Pustaka}

Arikunto, S. 2006. Metode Penelitian Kualitatif. Jakarta: Bumi Aksara

Asnamawati, Lina (2015) Strategi Percepatan Adopsi Dan Difusi Inovasi Dalam Pemanfaatan Mesin Tanam
Padi Indojarwo Transplanter Di Kabupaten Bengkulu Utara Provinsi Bengkulu. In: Prosiding Seminar Nasional FMIPA-UT 2015: Optimalisasi Peran Sains dan Teknologi Menuju Kemandirian Bangsa.

Banunaek Musa., 2017. Thesis. Analisis Kinerja Penyuluh Pertanian Lapangan (PPL) Kabupaten Boyolali Propinsi Jawa Tengah

Banunaek Musa., 2017. Pemberdayaan Untuk Meningkatkan Kinerja Penyuluh Pertanian di Kabupaten Boyolali. Jurnal Penyuluhan IPB. edisi Septernber 2017 Vol XIII No. 2.

BPS. Kabupaten Kupang. 2016. Kabupaten Kupang Dalam Angka 2016

BPS. Prov. NTT. 2016. Provinsi Nusa Tenggara Timur Dalam Angka 2016

Gibson, J.L., John M. Ivancevich, James H.

Donnelly Jr., and Robert Konopaske.

2012. Organizations: Behavior, Structure, Processes, Fourteenth Edition. Published by McGraw-Hill, a business unit of The McGraw-Hill Companies, Inc., 1221 Avenue of the Americas, New York, NY, 10020. Copyright (C) 2012 by The McGrawHill Companies Inc. All rights reserved. Previous editions (C) 2009, 2006, and 2003.

Irwandi D dan Susilawati., 2016. Peranan Penyuluh Pertanian dalam Adopsi Inovasi Padi Sistem Jajar Legowo di Lahan Pasang Surut. Prosiding Prosiding Seminar Nasional Inovasi Teknologi Pertanian Banjarbaru, 20 Juli 2016

Jalil, Rabu., Dkk 2015. Peran Penyuluh Dalam Program Model Kawasan Rumah Pangan Lestari (M-Krpl) Di Kabupaten Siak. Jurnal Jom Faperta Vol 2 No 1 Februari 2015. Fakultas Pertanian Universitas Riau. Pekanbaru Mardikanto. 2009. Sistem Penyuluhan Pertanian. Sebelas Maret University Press. Surakarta.

Ni Nyoman Ari Mayadewi. 2011. Inovasi Teknologi Pada Komoditas Padi 
Bagi Keberlanjutan Pembangunan Pertanian.

ejournal.undwi.ac.id/index.php/dwi jenagro/article/download/276/244

Ridwan, S. 2013. Skripsi. Persepsi Petani Terhadap Peran Penyuluh Pertanian Dalam Pengembangan Usaha Agribisnis Pedesaan (Puap) Di Kelurahan Lembah Damai Kecamatan Rumbai Pesisir Kota Pekanbaru Program Studi Agribisnis Fakultas Pertanian Universitas Riau. Pekanbaru.

Sugiyono. 2010. Metode Penelitian Pendidikan Pendekatan Kuantitatif, kualitatif, dan R\&D. Bandung: Alfabeta

Wirasyahputra Andrian., 2012 Tesis: Pengaruh Peran Penyuluh dan Kearifan Lokal Terhadap Adopsi Inovasi Padi Sawah di Kecamatan Montasik Kabupaten Aceh Besar. 